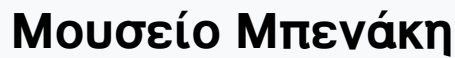

A Singular Antiquity: Archaeology and Hellenic Identity in Twentieth-Century Greece

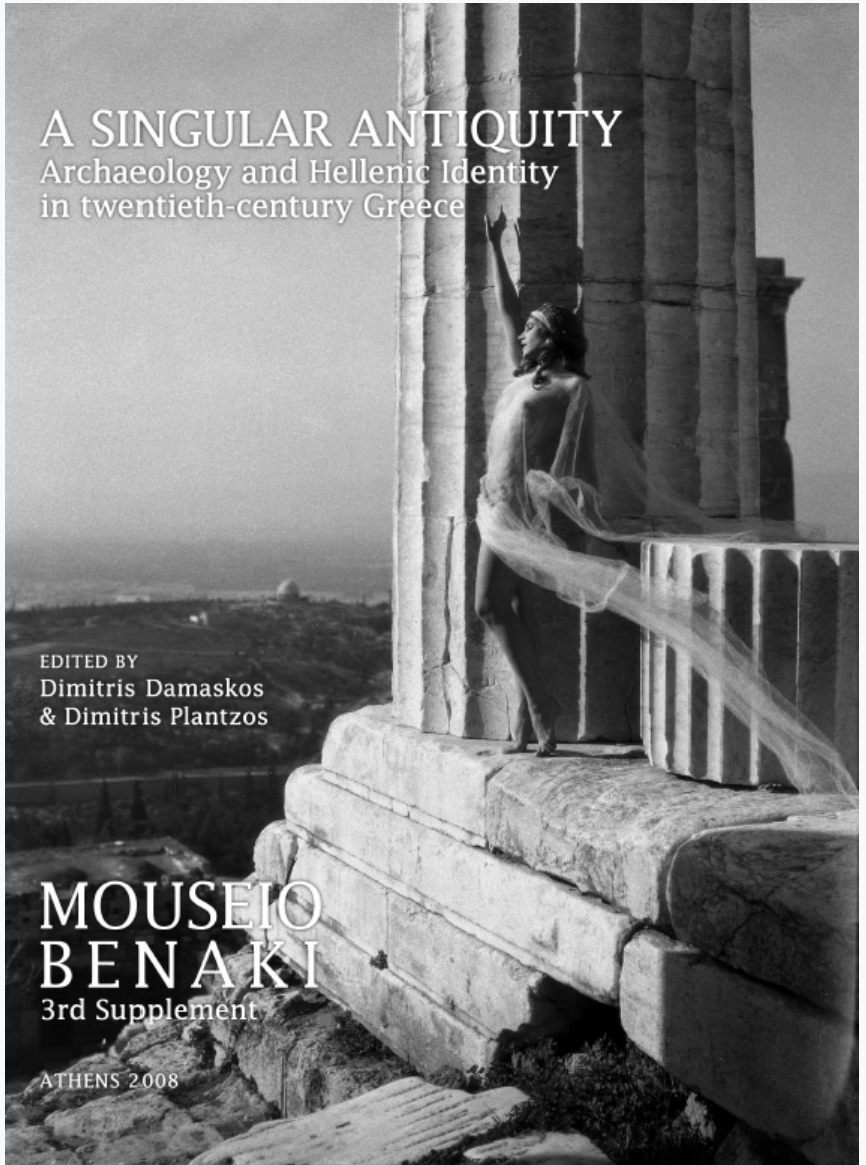

Reconfiguring the past: Antiquity and Greekness

Dimitris Tziovas

doi: $10.12681 /$ benaki.18048

Copyright $\odot$ 2018, Dimitris Tziovas

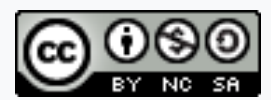

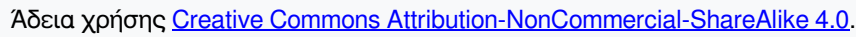

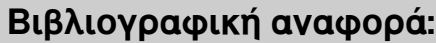

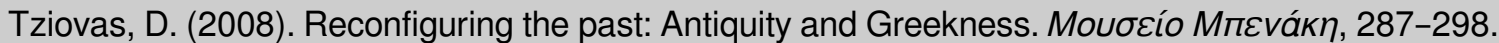

https://doi.org/10.12681/benaki.18048 
PART III.

THE IMAGINED

REALITIES

OF GREEKNESS 


\section{Reconfiguring the past: Antiquity and Greekness}

'When we contemplate ruins, we contemplate our future'.

C. Woodward, In Ruins (2001) 2.

A GREAT DEAL HAS BEEN written recently regarding the notion of Greekness, and though the debate has spilled over from the domains of literature and criticism into painting, music, architecture and now even to archaeology, little progress has been made towards elucidating the concept. Greekness can refer to all sorts of things including national character or cultural identity, the hellenocentric orientation of cultural activities, Greek themes or leitmotifs in painting, music and other arts, even when used by non-Greeks, or the overall distinctiveness of Greek culture. And these different meanings easily lead to confusion. Though, according to Stephanos Koumanoudis, the term 'Greekness' was introduced into the Greek language in 1851 by Konstantinos Pop, and Iakovos Polylas used it for the first time in critical discourse in 1860 in defending the Greekness of Solomos' poetry against Spyridon Zambelios, ${ }^{2}$ the debate over Greekness has been primarily centred on the thirties and the so-called 'generation of the thirties.' ${ }^{3}$ The paradox is that the literary representatives of this generation neither used the term extensively nor did they write any essays on the topic, at least not during the thirties, though they occasionally expressed their views on the subject in debates (e.g. G. Seferis and K. Tsatsos) or in articles responding to controversies over intellectuals such as Periklis Giannopoulos. Why then has the generation of the thirties been so associated with Greekness? So far no adequate explanation has been advanced and in this paper I will venture an interpretation by comparing some of the different ways in which modern Greeks perceive their past.

If we attempt to outline the main ways in which Greek intellectuals have approached their country's past, and particularly ancient Greece, over the last two centuries, it comes down to the following four. The first approach could be described as the symbolic or archaeological way, which thanks to an undervaluation of the Middle Ages highlighted the gap between the classical past and the present. The distance between past and present could be bridged either symbolically - whether in a revival of the classical past as an idealized model or in a process of purification whereby historical accretions and modifications are purged from ancient monuments, place-names or the language - or mechanically by constructing an artificial language such as katharevousa. As a consequence since the period of the Greek Enlightenment and throughout the nineteenth century Neoclassicism has prevailed in Greece and the words 'resurrection', 'revival' and the 'return of the Muses' were all met with equal frequency.

While the first approach relies on treating the past as an archaeological monument, something distant which can either serve as a symbolic model or a vehicle for comparisons, the second, which can be defined as holistic and romantic, envisages the past as a living presence in the sense that vestiges can be traced in modern cultural phenomena. This implies a transition from nostalgia for past glory to a search for a lost authenticity. Based on the idea that the past can be recovered as a material and visible presence, this paradigm underpinned the rise of folklore studies and the demoticist movement in Greece at the end of the nineteenth century.

The third approach, which could be called aesthetic or modernist, represents an extension of the first two in that it assumes the presence of the past not so much as a histori- 
cal survival but as a kind of aesthetic or stylistic continuity or a metaphorical equivalence. Thus the relationship between past and present is aestheticized while the notion of continuity is perceived aesthetically or metaphorically and not in material, historical or linguistic terms. The aestheticization of the past means that it loses its rigidity and becomes something that can be reassessed, revised or even rejected. Since the past permeates the present stylistically and aesthetically, continuity is implicit and cannot therefore be challenged by any doubts about the past or tradition.

This brings us to the fourth way of approaching the past which could be described as ironic, critical or postmodernist. Emmanuel Roidis, for example, was the first writer not to present katharevousa as a bridge between past and present, but rather to keep an ironic distance from it. Though not a fervent supporter of katharevousa, he uses it in his writings as a mask which is often ironized or demythologized. Since neither purity nor folk authenticity are sought by the followers of this approach in the area of language, in other domains too the rigid perception of the past retreats and it is no longer treated as a monument. In this approach the past is not considered a given or indisputable, but an entity which can undergo constant reinterpretation and revision, allowing suppressed aspects to emerge or acquire new significance. In this case the issue of historical continuity becomes less important and the focus shifts towards a sceptical unearthing and reassembling of the past. As a consequence classical antiquity, which is seen as the least problematic period, is side-stepped while less vaunted or more controversial periods such as the Hellenistic, the Byzantine or the Ottoman take centre stage. It may be useful to review these four approaches to the past, which of course are not the only possibilities, in greater detail - focusing primarily on the third approach, which in my view is most directly relevant to the question of Greekness.

As has already been said, the main concern of the first approach (a primacy justified even in chronological terms) is to bridge the gap between the distant past and the present. At least until the end of the eighteenth century this gap between the ancient and the modern world was partly promoted by the church which wished to remind people that they were first and foremost Orthodox Christians, at a time when the appellation 'Hellene' was still identified with the heathen. Even Korais uses the term
'Greek' for his contemporary compatriots; and when he refers to 'Hellenes' he means the ancient Greeks. ${ }^{4}$ In the same period, Greece was largely made up of agricultural communities, who experienced time in terms of the yearly cycle of sowing and harvesting or the biological cycle of life, and had only the vaguest picture of the past. A continuous timeline formed no part of their worldview. ${ }^{5}$

Before the Greek War of Independence (1821-1827) the connection with the classical period was not stressed. ${ }^{6}$ The historical books which were written or circulated in the Greek world up to the last quarter of the eighteenth century make reference to the Christian past and ignore Greek antiquity. The Christian perspective sees the world as God's creation, where progress is determined by the conflict between faith and unbelief, and human salvation is the central issue. The Enlightenment saw things quite differently. It put human beings, not God, at the centre of its universe, treating the past as a mirror held up to man's fortunes. From the 1790s on a sense of continuous time with all that implies started to develop.

An idea which gained in currency towards the end of the eighteenth and the beginning of the nineteenth centuries was the so-called 'return of the Muses'. After their temporary exile from Greece during the Ottoman period, or so the story goes, they sought refuge in Western Europe, subsequently returning to their homeland after its liberation. ${ }^{8}$ This is the line Kalvos took in his ode 'To the Muses' (1824):

\section{Your long exile}

has ended now.

A happier time returns

and the Delphic mount

beams in freedom.

The clear, silver water

of the Spring flows.

Its sounds are heard here.

Today Greece

calls her daughters back.

You came, o Muses,

I hear you!

My soul soars in bliss.

I hear what the lyre preludes.

I hear the hymns. 
Further indications of this increasing neoclassicism are the tragedies with ancient themes and the likening of some modern writers to classical counterparts (for example, Rhigas was often called 'the new Tyrtaeus', Christopoulos was described as 'the new Anacreon' and Kalvos was dubbed 'the new Pindar').

The elevation of antiquity into a glorious model served to highlight the discrepancy between an illustrious past and the pitiful present, as can be seen in the first modern Greek novel O Leandros (1834) by Panayiotis Soutsos: 'Do you share the melancholy I feel as I walk through these ancient ruins and the new settlements? Does this comparison between the great past of Greece and her little present make you sad?' ${ }^{10}$ One way to overcome this melancholic contrast was to revive the past by making not only the language more archaic, but also place-names and monuments. After Independence, many Albanian, Turkish or Slavic names of cities, villages and other place names were hellenized: Vostitsa, for example, became Aigion, Leontari was renamed Megalopolis, and Koulouri Salamis. This process of hellenization continued even in the twentieth century. In 1819 the Patriarch Grigorios V and the Holy Synod condemned in an encyclical the relatively recent innovation of giving ancient Greek names at baptism ${ }^{11}$ while in the 1830 s newspapers, periodicals and even roads, boats and industrial products acquired classicizing Greek names. ${ }^{12}$

As is well known, from 1836 to 1875 there was a systematic stripping of all post-classical additions from the Acropolis. ${ }^{13}$ The site was gradually divested of any 'remains of barbarity' with the removal of the minaret from the Parthenon and what was left of the Renaissance palace which had been built into the Propylaea. The clearance was completed in 1875 when the Archaeological Society at Athens, with the financial support of Schliemann, demolished the Frankish Tower. ${ }^{14}$ A historical palimpsest until 1821, after Independence the Acropolis rejected its historicity, demolishing large parts of its past. ${ }^{15}$

By revealing and restoring the past, classical archaeology contributed to the nation-building process, and was the most idealizing of disciplines since it perceived culture as a collection of masterpieces impervious to time. By seeking purity and perfection in the aesthetic form while trying to repair damage or restore monuments, nineteenth-century archaeology represented a rejection of history. Thus the past was treated as a monument untouched by time and historical developments, even though the notion of 'revival' underpinning many neoclassical and archaeological projects suggests an earlier process of decline or decay. In recent years, however, our approach to the past has changed; archaeology has ceased to be considered a holistic discipline which rejects the aesthetics of fragment or ruins, aspiring to revive the past and safeguard its truth. Archaeology is now treated as a discipline producing not just one past, but multiple histories from its fragments and ruins. ${ }^{16}$ In this respect, it helps us understand the transition from the traditional aesthetics of totality to the modernist aesthetics of the fragment. These two aesthetics, based on different perceptions of the past, can alert us to the way in which one reconfiguration of the past succeeds another.

This first, 'revivalist', approach to the past gave way to one stressing continuity, which saw Byzantium incorporated into the scheme of national history ${ }^{17}$ though, due to the language controversy, antiquity remained the area that both demoticists and purists claimed as their own. In this context language assumed the role of the most tangible sign of continuity as Psyharis argues in the following quotation: 'The ancient language has not been lost; you will find it in people's mouths. The ancient tongue will make you understand the modern and with the modern you will grasp the meaning of the ancient. Our demotic (romeiki) language is a continuation of the [ancient] Greek, but in order to represent this continuity it had to change otherwise it would have been forever the same'. ${ }^{18}$ The Greek people, who provide the vehicle for this continuity in their language, are living proof of its existence.

This continuity, however, could also be demonstrated in reverse manner by approaching the past through the perspective of the present. As Ioannis Sykoutris notes in 1928: 'No one who has not first been moved by the demotic songs such as Erotokritos or Palamas' King's Flute - not to mention the European epic - could ever respond to Homer. And in turn Homer will help them to assess these things and to award them the place they deserve'. ${ }^{19}$ This is more of an aesthetic and emotional continuity which can be seen as involving a leap from modern to ancient Greece and vice versa.

The conception of the past as an organic entity often leads to a nation turning in on itself and rejecting any foreign influences. In the name of continuity and the organic cohesion of the national body foreign cultural 
and linguistic influences are denounced as subversive and dangerous. For example, in the 1880 s the practice of translating European school textbooks for use in Greece was abandoned and instead textbooks written by Greeks began to be preferred. ${ }^{20}$

It has been said that the bipolar arrangement of classical past vs. modern present, predicated on the distance as opposed to the continuity between them, was to some extent maintained by archaeology which, until the end of the nineteenth century, focused almost exclusively on Athens and its classical past. After Schliemann's discoveries at Mycenae in 1876 the notion of linear continuity transcended the classical past and was extended to prehistory, with archaeological interest spreading to embrace a wider area and not just classical Athens. ${ }^{21}$ Thus archaeology engendered an expansion in terms of time and space which in turn questioned the approach based on the divergence between the classical past and the present, and this expansion coincides with developments in historiography.

The notion of continuity in time went hand in hand with that of unity in space (the 'Great Idea') and in this respect the ancient world could not offer a model of unity, since in the eyes of many historians it was its very fragmentation that led to it succumbing to the Macedonians. In his History of the Hellenic Nation (1850-1874) Konstantinos Paparrigopoulos offered, on the one hand, uninterrupted continuity by rehabilitating Byzantium and, on the other, unity in space by embracing at the same time Athens and Constantinople. Where the ancients offered the myth, Paparrigopoulos offered the grand narrative of Hellenism. It could be argued that these two approaches to the past correspond to the two theories of nationhood: national reawakening and national construction.

If in the first approach the past represents an indisputable model and in the second a way of laying claim to some overall continuity in the Greek people and their culture, in the third approach it functions as an archetype, that is to say as a deep structure which is reactivated and recharged by being exploited in artistic terms. Thus it combines the monumental solidity of the former approach with the emphasis on the living presence of the latter. In this approach the essence of the archetype, that is the monumental or ontological conception of the past, is of secondary importance, since the primary emphasis is on its potential for transformation and recreation. Unlike more decadent, controversial or marginalised periods, antiquity, with its well-known myths (e.g. Jason and the Argonauts) or figures (e.g. Odysseus), lends itself to an archetypal approach to the past.

The archetypal pattern, as a kind of deep structure and a version of the aesthetic-modernist approach mentioned earlier, combines stability and constant revival and reference to tradition without excluding any fruitful renewal, thus promoting the idea of a core essence without risking fossilization. Perhaps by exploring this archetypal idea in its different forms and versions, we might find the clue to understanding how the issue of Greekness emerged during the thirties.

By constantly revisiting and reshaping history the archetypal approach ensures the relative uncertainty of the past while giving greater priority to the present. The challenge of relativity is tackled not by insisting on a rigid tradition, but by promoting an aesthetic idea, a diachronic spirit or abstract quality. As an abstract and timeless concept, Greekness therefore counterbalances the relativity of tradition and facilitates the dialogue between history and aesthetics, past and present, Greece and Europe. In order to understand the relationship between the archetypal poetics of the past and Greekness better, these pairs will be discussed in turn below.

The archetypal perception of the past both emphasizes and at the same time tries to paper over the cracks between history (tradition) and aesthetics (modernity), as George Seferis has described with reference to the Parthenon:

'In the Parthenon [...] we have indeed two completely different emotional triggers side by side in the same object. One, the historical, archaeological or what we might call the cyclical, makes me daydream of travelling to the past; reflect on the futility of human affairs; raise the flag of insurrection against Morosini's cannonballs; be ecstatic in the face of the beauty of the life of the ancient Greeks. The other, the aesthetic, is a completely different matter; a sudden presence, something intense and exclusive; a marble cloak covering me from head to toe; a voice which I do not understand, though I feel an urgent need to speak like it in order to understand it. ${ }^{22}$

What could bridge the gap between the historical and the aesthetic, which manifested itself so strongly in the thirties, was a spiritualization of tradition and an aestheticization of Hellenism, namely Greekness. At that time 
Greekness was not, as some people think, considered either in terms of unreflecting ethnocentrism or a simple appropriation of traditional motifs in a text or painting; it emerged as an aesthetic arrangement allowing past and present to speak to one another, linking the archaism of myth with the historicity of the present. However, for the archetypal approach to work effectively, and co-ordinate the reworkings of the past, it required abstraction and aestheticization.

During the thirties this very issue of the communication with the past and the dialogue with tradition emerges in some of Seferis' poems which take antiquity as their theme. In Mythistorema (1935), for example, the past is presented as an archetypal source ('Still one more well inside a cave.l It used to be easy for us to draw up idols and ornaments' [2]), but also as an exhaustive burden ('I woke with this marble head in my hands' [3]); the archetypal ritualistic repetition is also implied in the poem ('so that the age-old drama could begin again' [1]), though at some point it leads to the break up of the cycle ('the ancient dead have escaped the circle and risen again' [21]). ${ }^{23}$

Moreover, in his novel Argo (1933-36) Yorgos Theotokas tries to orchestrate this dialogue between past and present using the metaphor of the Argonauts, the mythical quest and the Greek nation's endless journey. On the whole, this archetypal approach treats the past, and by extension tradition, as a burden and at the same time as a gift which conceals its potential for creative exploitation. This twofold and in a sense contradictory conception of the past may help us to understand how Seferis and Theotokas challenged tradition while endeavouring to highlight its hidden or underdeveloped aspects.

Mythical associations and modern uses of the past raise the question as to what links these various versions of the archetype, and this, in turn, leads to a definition of tradition as both stable and flexible, combining the renewal which comes with the passage of time with a sense of the past as an unchanged archetypal source. In 1938 Seferis addressed the question of the literary past in this way:

'For every work of art that comes to be added to the series affirms and at the same time modifies the meaning of the older masterpieces. Dante, for example, does not have the same meaning before and after Baudelaire, nor Racine before and after Valéry, nor the Elizabethans before and after T.S. Eliot. Thus we may establish a kind of correspondence between Homer and Virgil, Homer and Aeschylus, Aeschylus and Euripides, or, in our modern poetry, between Kalvos and Cavafy. This is a living tradition and it is in this way - not solidified and unchangeable - that works of art live'. ${ }^{24}$

The archetypal perception of the past combines its reduction to essentials with the introduction of the notion of relativity and the sense of a living presence. This living presence, however, as can be seen in the passage from Seferis, does not so much involve a visible, material or evidential organic continuity of tradition, as understood by folklorists or demoticists, as tradition's potential to generate renewal and change from within. This is an underlying intuitive continuity which challenges the monumentality of the past as becomes clear in Seferis' poems 'Reflections on a Foreign Line of Verse' (1933) and 'The King of Asine' (1940). In the former Odysseus is the archetype which is transformed, the ghost who returns, the anti-hero who survives in the old sailors who recite the Erotokritos and teach humble craftsmanship. In the other poem, the poetic subject tries, from a starting point in the present and using his sense of touch and intuition, to communicate with the unknown ancient king, to fill the gap

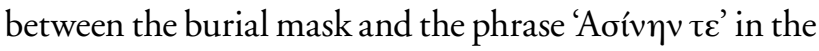
Iliad. By treating the king as a metaphor for the past, we can see how uncertain and fluid the past is for Seferis, but also how alive it is, as he moves around the place 'with the ancient monuments and the contemporary sorrow'. ${ }^{25}$

Both poems are based on reading the past with the help of textual fragments. The past is not transmitted as a closed and given whole, but as an open fragment, giving the opportunity to complete and restructure it through memory. The archetypal approach presupposes a dialogic and agonistic relationship between past and present, with memory acting as the 'present past ${ }^{26}$ and its basic mechanism.

The anti-monumental perception of the past and the relativity of tradition can no longer be expressed by an ontological and rigid conception of the past, but only through transformations or changing relationships; this encourages an aesthetic or intuitive approach which tries to explore a unique style, an exceptional aesthetic feature or a sense of the landscape. The relativity is not tackled so much by insisting on an unyielding sense of tradition as by demonstrating an aesthetic quality, a diachronic spirit or an abstract pattern. The modernist awareness of rela- 
tivity, which manifests itself during the thirties, and particularly in Seferis' way of looking at things, leads to the development of an aesthetic and abstract counterbalance, which will express both eternity and transience, essence and transformation. Hence, Greekness is at the same time a timeless quality and the outcome of relations, in the same way that archetypes entail, on the one hand, the deep and immutable structure of a primordial core and, on the other, the relativity of the past thanks to constant transformations, thus acknowledging some sort of conditional priority in the present.

Greekness, therefore, is not an essential or measurable quality, but an intuitive combination and an aesthetic synthesis. This is implied by Seferis when he describes a small painting by El Greco, a saint's portrait, which he saw during a visit to the National Gallery in London:

'More than ten years have passed since I saw this picture for the first time. I cannot forget the overwhelming impression of "Hellenism" that was conveyed to me by this minor example of the great master's work. I still remember two brush strokes on the shoulders: "Like Cretan fifteensyllable lines", said the friend who was with me. We were young then. Sometimes there is a foreknowledge of this "Greek Hellenism" among some of the best of us, "for wise men perceive what is approaching", ${ }^{27}$

By an aesthetic association El Greco's painting and the Cretan fifteen-syllable line produce this 'overwhelming impression of Hellenism'. By highlighting associations, allusions and metaphors, as Seferis' mythical method or Theotokas' Argo seem to suggest, Greekness appears to be both something enduring and changeable. This perception of Hellenism as both being and becoming can only be conveyed by an aesthetic conception of Greekness. ${ }^{28}$

Therefore, the Greekness that the generation of the thirties promoted has nothing to do with ethnocentric navel-gazing or xenophobia but highlighted Greek culture as a sort of archetype which assumed a variety of guises over the years. During the thirties the dominant version is more mythical, topographical (with the emphasis on the Aegean) or stylistic while after World War II it becomes less classicizing and more historically defined with the rediscovery of Byzantium, the 'Greek Hellenism' of Makriyannis, Theophilos or even the Orthodox Church. The reasons for this transition from the mythical to the historical archetypal approach have something to do with the experience of war and the German occupation but also with the accusations made by other critics that the generation of the thirties was not Greek enough.

The archetypal perception of the past leads to Greekness because by using this approach the generation of the thirties was able to point up and valorize those deeper, timeless features of Greek culture which could facilitate a fruitful and equal dialogue with Europe. If eighteenthcentury Greece is an ideological construct of colonialist Europe without ever having been, strictly speaking, colonized, ${ }^{29}$ a place sacred as the mythical ancestor of European civilization and polluted due to barbarous Ottomanism, at the same time pan-European and Oriental, familiar and exotic, ${ }^{30}$ then during the thirties there was an attempt to transform this exotic land into something familiar, so that 'European Hellenism' and 'Greek Hellenism' might be able to converse with one another. ${ }^{31}$

Up to the thirties the relationship between Greek and European culture was discussed in terms of imitation, westernization or rejection of foreign influences whereas the generation of the thirties was seeking a creative dialogue and promoted the idea of cultural reciprocity. But for a meaningful dialogue and a mutual exchange to develop, Greece had to be in a position to offer something lasting, different and of international interest which would emerge from the archetypal womb of Hellenism, not something fake or superficial. In this way the archetypal approach guarantees authenticity, and, in turn, leads to Greekness and also to modernity as a creative renewal of tradition. However, this Greekness is not recalcitrant ethnocentrism; instead it represents an attempt to develop the necessary conditions to allow Greek culture to re-enter the process of cultural exchange and competition, not simply as a mere descendant of the classical ideal but as a modern, original and vibrant cultural partner.

The generation of the thirties raised the issue of balancing modernity and tradition, westernization and Greekness not only as an aesthetic or artistic problem, but as a wider cultural challenge. Through the archetypal approach and dialogue with Europe on equal terms this generation developed a view of the relationship between tradition and modernity, locality and universality which has yet to be superseded, recurring as it does in Greek discussions about the European Union or globalization. For this generation the issue of Greekness could be summed 
up as what Greece could offer to the world which would be genuinely indigenous and would attract universal attention. They conceived Greekness in terms of the problematic cultural identity of neo-Hellenism in relation to its classical past and an issue of cultural dialogue and mutual exchange with Europe. For this reason this generation casts a heavy shadow over cultural debates in Greece today, with younger generations of writers and critics being judged unfit to compete with it either in terms of artistic achievement and self-promotion outside Greece or by developing different views on Greekness which could render its own obsolete.

The first two approaches to the past, mentioned earlier, correspond to some of the ways in which Europe saw the past, that is either as a political ideal and aesthetic model based on the rediscovery of Greek antiquity or through the ethno-romantic perspective of organic continuity and racial, geographic and cultural homogeneity. Each aspired either to meet European expectations as exemplified in Adamantios Korais' well-known address to the French public in $1804^{32}$ in which he endeavoured to draw parallels between modern and classical Greece, or to respond to European challenges, as Paparrigopoulos and other historians did in their attempts to refute J.P. Fallmerayer's claims. In other words they do not suggest a new approach, but simply adopt the theoretical armoury of Europe in order to respond to challenges emanating from Europe and to advance various aims such as to establish that Greeks had some sort of special status in the Ottoman Empire because of their glorious ancestry, to promote the theory of Greek racial purity and national continuity or to argue for linguistic change following the example of Europe with its transition from Latin to the vernacular. In all these cases Europe served as a model and a vehicle while Greece was a 'European' Greece. The first two approaches do not aspire to develop a dynamic Greek 'myth' but adopt either a passive role in accepting the myth which Europe had already constructed around the glory of ancient Greece or a defensive one advancing the dogma of national continuity whenever their racial purity was challenged.

The third approach, the archetypal, recognises Europe as the creator of what Seferis called 'European Hellenism'. For the first time, however, it tries to offer something alternative: 'Greek Hellenism', or Greekness. While the earlier approaches followed Europe by responding to is- sues first raised there or entering into debates based on European ideological concerns, in the archetypal approach one senses the desire for a cultural dialogue on equal terms which was to combine, for example, European modernism with Makriyannis' simplicity. The aim of the first two approaches is purity and homogeneity, and, therefore, the perception of Hellenism is primarily ontological; in the third approach, without abandoning the belief in the continuity of Hellenism, Greekness emerges intuitively and stylistically as a result of fresh associations, reconfigurations and rethinking of the past. In the first two approaches Greekness works in causal or evidential terms, in the third it is perceived aesthetically. The fourth approach is based on irony and Greekness is relativized, hybridized or contested.

Characteristic examples of this approach are Cavafy's poems 'Philhellene' (1912) and 'A Prince from Western Libya' (1928). In the first poem, which takes the form of a dramatic monologue, an Asian monarch gives instructions to his courtier Sithaspis for the engraving of a coin in the Greek style thus claiming not only the title of the Philhellene, but also a knowledge of Greek.

Now don't try to be clever

With your 'where are the Greeks?' and 'what Hellenism here behind Zagros, out beyond Phraata?'

Since so many others more barbarian than ourselves choose to inscribe it, we'll inscribe it too.

And besides, don't forget that sometimes sophists do come to us from Syria, and versifiers, and other triflers of that kind. So we're not, I think, un-Hellenized. ${ }^{33}$

The Philhellene is aware that his claim to Greekness is problematic; he insists, however, on projecting an artificial Greek image which he himself ironically undermines. In this poem Greekness is a superficial construct as in the poem, 'A Prince from Western Libya', where again Greekness is claimed on the basis of language, while irony and sympathy go hand in hand:

He wasn't a profound thinker or anything at allJust a piddling, laughable man.

He assumed a Greek name, dressed like the Greeks, learned to behave more or less like a Greek; and all the time he was terrified he'd spoil 
his reasonably good image

by coming out with barbaric howlers in Greek and the Alexandrians, in their usual way, would start to make fun of him, vile people that they

are.

This was why he limited himself to a few words, terribly careful of his syntax and pronunciation; and he was driven almost out of his mind, having so much talk bottled up inside him. ${ }^{34}$

For Cavafy Greekness lies in constructing a mask, which can be undermined by irony, thus emphasizing the arbitrariness as well as the accessibility of the Greek identity.

Cavafy, as E.M. Forster argued, reacts to the tyranny of classicism ${ }^{35}$ and ignores mainland (classical) Greece, which is mentioned only twice in his 154 canonical poems. He himself was not bothered, as other Greek intellectuals were, by the incongruities between the European ideal and the Greek reality; what interested him instead was the syncretism of the vast Greek world which, after the conquests of Alexander the Great, embraced a number of peoples who were neither racially nor linguistically Greek.

The Hellenistic period attracted the attention of other writers apart from Cavafy, such as the novelist Rodis Roufos, who in 1967 published his novel Graikyloi (reprinted in 1971 and 1999). In an essay which preceded the publication of the novel Roufos disagreed with the perception of the Hellenistic period as decadent, arguing that it was a period of maturity rather than of senescence. ${ }^{36}$ Focusing on the individual or the universal and no longer on the city, the Hellenistic period promoted cosmopolitanism, individualism and scepticism, challenging traditional views and values. The modern antipathy towards mature periods such as the Hellenistic, Roufos points out, is a psychological reaction to the fact that the post-classical period presents some analogies with our own age, something that Cavafy was aware of and utilized.

Roufos places the action of his novel in Athens during the period 88-86 $\mathrm{BC}$, offering a historically accurate picture of the period based on documentary sources and presenting a city divided between the democrats, who wanted to get rid of the Romans with the help of Mithridates, and the oligarchs, who were loyal to Rome. Though Dion, the main character in the novel and an imaginary figure, is a democrat sympathiser, he does not wish to see Athens becoming Mithridates' colony.

The opposition between Rome and Mithridates can be seen as a metaphor for the conflict between East and West, or communism and capitalism during the cold war, given that the novel deals with the paranoia of power and the ethics of totalitarianism. Caught between these extremes Dion seems to unite liberalism with Hellenism, providing a shorthand signifier for Hellenism:

"Fearlessly and bravely". This is Greece in a nutshell, her true power, her mission. Calm courage, dignity, acceptance of the tragic business of life. [...] "Fearlessly and bravely". This is what will survive of Hellenism, this will not be destroyed by the legions. If the world should ever be overshadowed by new barbarians and superstitions, may the word "Greek" continue to mean someone who keeps a fearless and impartial mind $[\ldots]^{\prime 37}$

Dion is the personification of humanism and aestheticism, thus indirectly supporting the viewpoint of the novel which is that all beautiful things are somehow Greek, whereas Rome and Mithridates represent barbarism. Judging from the title of the novel, Graikyloi (Lat. graeculi = 'little Greeks'), a pejorative name used by the Romans for the decadent Greeks of their day, it is their culture which will help the Greeks recover their independence, not political power. Politics is disdained in the novel as being driven by greed and based on arrogance and corruption. Culture, on the other hand, is connected to the ideals of Hellenism and is represented in the novel by Dion who emerges as the aesthetic counterbalance to politics. The novel could be read as an allegorical comment either on a national level, and thus connected to the situation in Greece during and after the civil war, or, if we see the conflict between Rome and Mithridates as an allegorical projection of the conflict of the two superpowers at the beginning of the cold war, on an international level. ${ }^{38}$

Roufos presents the quiet humanism and the aesthetics of Hellenism as an antidote to political barbarism. Even if one sees this position as a form of idealism or escapism, he appears to combine the archetypal with the relativist approach to the past. Being a descendant of the generation of the thirties, he believes in the aesthetic power of Hellenism, but living in a politically turbulent period he is also aware of the political message of taking an ironic 
and critical stance towards the past. And in this respect he is helped by the fact that he turns his attention to the Hellenistic period and not to classical antiquity.

Graikyloi apart, the general perception remains that the archetypal approach to antiquity belongs more to poetry than fiction. Novel and antiquity in Greece seem two incompatible categories. ${ }^{39}$ As a genre the novel usually takes a critical and demythologizing attitude. Classical antiquity by contrast inspires pride and awe. The Hellenistic or Late Roman periods, on the other hand, are known as periods of decline or exhaustion. Yet some would argue that Cavafy exploited the Hellenistic period better than any novelist. The novel deals with the present more than any other literary genre; even when it alludes to the distant past these references lead to the present as in the cases of Theotokas and Roufos, two kindred political writers mentioned earlier. The novel by definition is liberating since the novelist who practises his art has never felt the burden of the past like a poet:

I woke with this marble head in my hands;

It exhausts my elbows and I don't know where to put it down. ${ }^{40}$

The fourth approach, being more ironic and sceptical, has manifested itself in recent years more in the area of fiction with a number of writers trying to bring to the fore forgotten or suppressed aspects of Greek history, and especially those related to the Ottoman and the Balkan past. The debate surrounding the representation of antiquity fuelled by textual fragments, multiple versions or the controversial role of various scribes, copyists and commentators can be placed within the context of this approach. This historiographical concern is encapsulated in The Novel of Xenophon (2004) by Takis Theodoropoulos, one of the few recent Greek novels to deal with antiquity. As stated on the cover of the book 'this is a novel about a period in which the Greek world is in decline', thus confirming the view that, when they focus on antiquity, Greek novelists prefer periods of transition rather than glory. Thus Theodoropoulos focuses on Xenophon and not on Thucydides.

Earlier, of course, the Greek Left had expressed doubts about the idea of continuity between modern Greece and antiquity and had begun to pay more attention to Byzantium and popular culture. In one of its congresses the
Communist Party, on the recommendation of its leader Nikos Zahariadis, tried to dissociate antiquity from modern popular culture by placing the emergence of a modern Greek consciousness in the Ottoman period..$^{41}$ A similar argument was put forward by the left-wing writer and intellectual Dimitris Hatzis, who in 1954 argued:

'In the domain of literary production, and of intellectual life generally the modern Greek world remains completely cut off from its ancient Greek cultural heritage. [...] No trace of survival or memory could be found anywhere. Continuity here is deeply, radically and completely broken. Modern Greek literature is the literature of a completely new world' ${ }^{42}$

It was not only the Left which subscribed to this ironic and sceptical approach to the past. The demythologizing of antiquity in poems such as 'Acropolis' (1933) by Nicolas $\mathrm{Calas}^{43} \mathrm{can}$ also be seen as part of the fourth approach. In this poem Calas sees the Parthenon not only as part of the national imaginary which needs to be demythologised, he also treats it as a symbol of the upper classes which has to be undermined and, judging from his ironic use of the word 'Parthenos', as part of Psyharis' lingustic orthodoxy. Calas mentions the Swiss photographer Fred Boissonas and the dancer Delilah in an allusion to the dancers Paiva and Nikolska, who had been photographed semi-naked by Nelly in 1927 and 1929 on the Acropolis, ${ }^{44}$ which allows him to criticize, in a roundabout fashion, the touristic exploitation of the Parthenon (see the reference to Karl Baedeker in the poem) and its use as a theatrical backdrop.

In his poem Calas subverts the romantic classicism associated with the Acropolis by introducing modern imagery to undermine the emblematic role of the Parthenon and calling into question the ideal of classical harmony through the poem's syntactical anarchy and its lack of punctuation. The ironic juxtaposition of an idealized past with the modernity of the present, also evident in the poem 'Tram and Acropolis' (1938) by Nikos Engonopoulos, underlines the breakdown of the relationship between art and tradition, and confirms Calas' belief that 'art is a powder-keg, and the proof is the Parthenon!'. ${ }^{44}$

Calas' poem brings to mind another 'satirical' poem, 'Delphic Festival' (1927) by Kostas Karyotakis, ${ }^{45}$ in which the deeper meaning of tragedy is contrasted with the 
technological glamour and spectacular shallowness of the contemporary age, summed up as 'the spirits of two [different] Greeces', namely the classical and the modern. As the poem suggests attempts to revive the classical spirit lead nowhere but to 'sacred silence'.

I have attempted to outline the modern Greek ways of approaching or reconfiguring the past and to cast some light on the much debated concept of Greekness. In conclusion, it could be said that the first two approaches are interested in the monumentalization, the purification and the hellenization of the past while incorporating neglected periods of history; the third is concerned with aestheticizing the past and the fourth with relativizing it using the experience of the present. In these four approaches past and present are connected using the relevant emblematic concept tools for each approach: revival, continuity, mem-

\section{Notes}

1. Woodward 2001, 2.

2. Tziovas 1989, 35.

3. Vayenas et al. 1997; Kayialis 2007.

4. Kakrides 1963a, 253; $1963 \mathrm{~b} 77$.

5. Politis 1997, 12; Politis 1998, 2.

6. Clogg 1996, 10.

7. Politis 1997, 14; Politis 1998, 4.

8. Mackridge 1994.

9. Kalvos 1998, 40.

10. Soutsos 1996, 57-58.

11. Reprinted in Dimaras 1953, 299-304.

12. Politis 1993, 108.

13. It could be said that this practice has been revived today by plans to demolish listed buildings which obstruct the view of the Acropolis from the new Museum built nearby. These proposals suggest a desire to link the classical past with the present by obliterating or ignoring vestiges of the periods in between.

14. Beard 2002, 101-2; Hamilakis 2003.

15. Something similar occurred in the twentieth century with the demolition of mosques or other Ottoman buildings after the exchange of populations and the departure of Muslims from Greece (Herzfeld 2001, 21). ory and irony. I should stress that the list I have given is not exhaustive nor are the approaches themselves always clear cut. Moreover, they do not succeed one another chronologically, and, thus are not clearly demarcated and do not work in isolation but overlap one another, with elements of continuity and transformation. They may nevertheless offer a useful guide to distinguishing the Enlightenment, the ethno-romantic, modernist and post-modernist approaches to the Greek past.

\section{Dimitris Tziovas}

Institute of Archaeology and Antiquity

Centre for Byzantine, Ottoman

\& Modern Greek Studies

University of Birmingham

d.p.tziovas@bham.ac.uk
16. Hamilakis 2004 and Jusdanis 2004. The changes in archaeology are related with a shift in approaching the landscape. While earlier the landscape was treated as eternal, atemporal and ahistorical, as an object external to perception, now it is viewed as a vehicle of history and ideas that the analyst tries to understand. The archaeological landscape is no longer perceived as a museum exhibit, cut off from the social context, but as historically and ideologically charged (Athanassopoulou 2002, 276).

17. 'The appropriation of the Byzantine period is of major significance because it represents the transition from one structure of the historical imagination to another: from the schema of revival to one of continuity. This transition is primarily a matter of the concept of historical time. Once this transition has been accomplished, each historical period finds its place within this schema' (Liakos 1994, 183; Liakos 2001, 32).

18. Psyharis 2001, 146.

19. Sykoutris 1997, 57. Some years later, in 1936, Sykoutris pointed out: 'I have written it (and I still believe it) that our contact with our spiritual (not the national) values of the ancient Greeks, our natural descendants, will develop only through the needs, problems and values of the contemporary European culture and not directly' (Sykoutris 1997, 233-34).

\section{Koulouri 1988, 24-26.}

21. Voutsaki 2003, 246-51. The Archaeological Society gradually started excavating outside Athens and in 1871 asked for permission from the Greek Government to appoint curators for ancient sites in the provinces (Kokkou 1977, 122). 
22. Seferis 1975,85 .

23. Seferis 1995, 4-25.

24. Seferis 1975, 21; Seferis 2000, 81.

25. Seferis 1995, 135.

26. Terdiman 1993, 8.

27. Seferis 1975,30 ; Seferis 2000 , 94-95.

28. Gregory Jusdanis $(1991,82-83)$ argues that the aestheticization of culture is a product of modernity and the generation of the thirties simply gave the autonomous operations of art an indigenous respectability.

29. Gourgouris 1996, 6.

30. Herzfeld 1987, 7; 19.

31. These terms have been introduced by Seferis $(2000,94)$ who seems to mean by them the classical ideal and the perception of ancient Greece developed in Europe since the Renaissance on the one hand and the perception of Greek culture developed in Greece proper since Independence on the other.

32. Korais 1970.
33. Cavafy 1979, 31.

34. Cavafy 1979, 114.

35. Forster 1926, 94.

36. Roufos 1971.

37. Roufos 1999, 419-20.

38. Tziovas 2006.

39. Though the novel is presented as a modern genre, it could be argued that it shares with archaeology the idea of gradual exposure, the careful unmasking which allows the hidden or the buried to be gradually revealed.

40. Seferis $1995,5$.

41. Kastrinaki 2005, 260; Matthiopoulos 2003, 459-60.

42. Hatzis 2005, 83-84.

43. Calas 1983, 23-24.

44. See Damaskos, this volume.

45. Calas 1977, 73-74.

46. Karyotakis 2006, 130.

\section{REFERENCES}

Athanassopoulou E.F. 2002: An 'ancient' landscape: European ideals, archaeology, and nation building in Early Modern Greece, Journal of Modern Greek Studies 20, 273-305.

Beard M. 2002: The Parthenon (London).

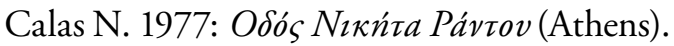

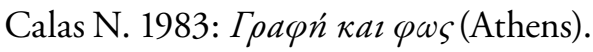

Cavafy C.P. 1979: Collected Poems (trans. E. Keeley \& P. Sherrard, London).

Clogg R. 1996: Sense of the past in pre-Independence Greece, in: Anatolica: Studies in the Greek East in the 18th and 19th Centuries (Aldershot) 7-30.

Dimaras K.Th. 1953: O Kopańs kaı n enoxń tov (Athens).

Forster E.M. 1926: Pharos and Pharillon (London).

Giannakopoulou L. 2002: Perceptions of the Parthenon in Modern Greek poetry, Journal of Modern Greek Studies 20, 241-72.

Gourgouris S. 1996: Dream Nation: Enlightenment, Colonization and the Institution of Modern Greece (Stanford).

Hamilakis Y. 2003: Lives in ruins: antiquities and national imagination in Modern Greece, in: Kane S. (ed.), The Politics of Archaeology and Identity in a Global Context(Boston) 51-78.

Hamilakis Y. 2004: The fragments of modernity and the archaeologies of the future, Modernism/modernity 11, 55-59.

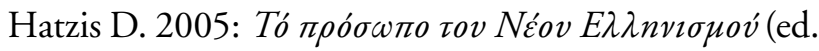
by V. Apostolidou; Athens).

Herzfeld M. 1987: Anthropology Thorough the Looking Glass: Critical Ethnography in the Margins of Europe (Cambridge).

Herzfeld M. 2001: Towards an ethnographic phenomenology of the Greek spirit, Mediterranean Historical Review 16, 13-26.

Jusdanis G. 1991: Belated Modernity and Aesthetic Culture: Inventing National Literature (Minneapolis).

Jusdanis G. 2004: Farewell to the classical: excavations in modernism, Modernism/modernity 11, 37-53.

Kalvos A. 1998: Odes (trans. by G. Dandoulakis; Nottingham). 
Kakrides J.Th. 1963a: The ancient Greeks and the Greek War of Independence, Balkan Studies 4, 251-64.

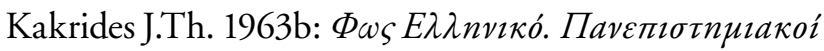
1óyor (Athens).

Karyotakis K. 2006: Battered Guitars: Poems and Prose (trans. by W. W. Reader \& K. Taylor; Birmingham).

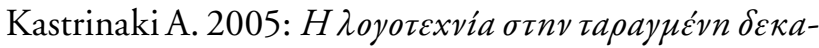
Exía 1940-1950 (Athens).

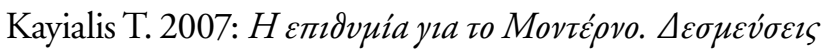

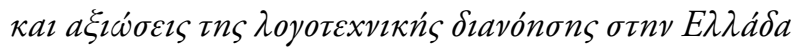
cov 1930 (Athens).

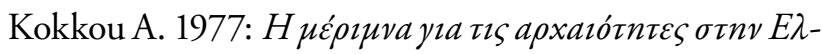

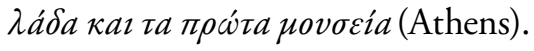

Korais A. 1970: Report on the present state of civilization in Greece, in E. Kedourie (ed.), Nationalism in Asia and Africa (New York) 153-88.

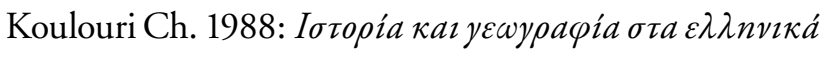

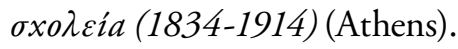

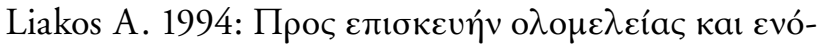

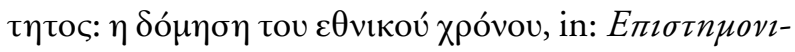

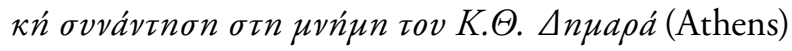
171-99.

Liakos A. 2001: The construction of national time: the making of the Modern Greek historical imagination, Mediterranean Historical Review 16, 27-42.

Mackridge P. 1994: The return of the Muses: some aspects of revivalism in Greek literature, 1760-1840, Káunos: Cambridge Papers in Modern Greek 2, 47-71.

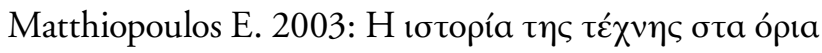

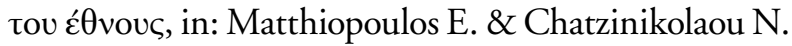

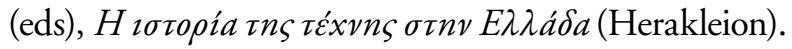

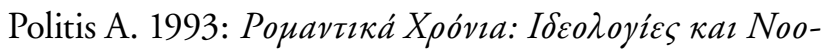

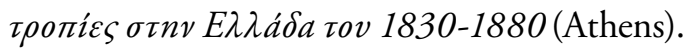

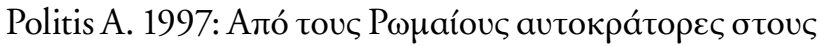

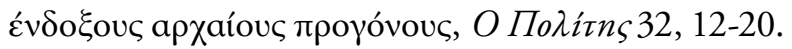

Politis A. 1998: From Christian Roman emperors to the glorious Greek ancestors, in: Ricks D. \& Magdalino P. (eds), Byzantium and the Modern Greek Identity (Aldershot) 1-14.

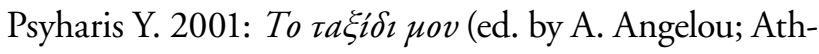
ens).

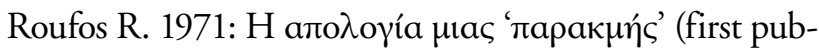
lished in the periodical Enoxغ́s $s$ in 1966) [reprinted in: $O \imath$

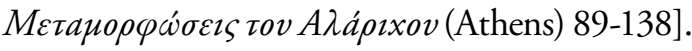

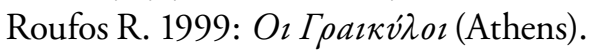

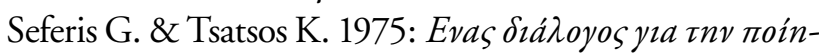
$\sigma n$ (ed. by L. Kousoulas; Athens).

Seferis G. 1995: Complete Poems (trans. by E. Keeley \& P. Sherrard; London).

Seferis G. 2000: On the Greek Style (Limni, Evia).

Soutsos A. 1996: O $1 \dot{a} a v \delta \rho o \varsigma$ (ed. by A. Samouil; Athens).

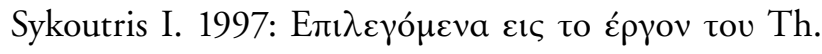

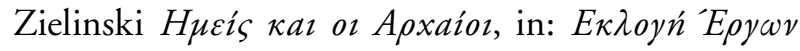
(Athens) 25-63.

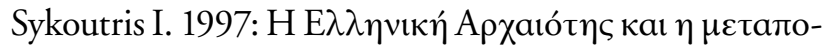

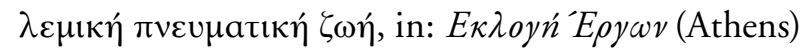
233-54.

Terdiman R. 1993: Present Past: Modernity and the Memory Crisis (Ithaca \& London).

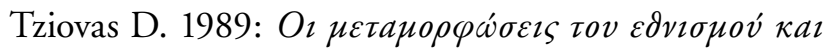

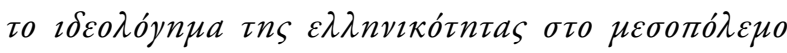
(Athens).

Tziovas D. 2006: Transcending politics: symbolism, allegory and censorship in Greek fiction, Káunos: Cambridge Papers in Modern Greek 14, 65-102.

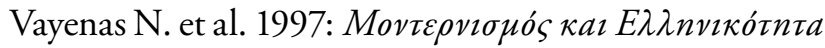
(Herakleion).

Voutsaki S. 2003: Archaeology and the construction of the past in Nineteenth Century Greece, in: H. Hokwerda (ed.), Constructions of [the] Greek past: Identity and Historical Consciousness from Antiquity to the Present (Groningen) 231-55.

Woodward Ch. 2001: In Ruins (London). 